\title{
New Perspectives and Competences as Needs for Advancement
}

The open-access peer-reviewed journal Baltic Journal of European Studies $(B J E S)$ has been published for five years by now. During this time, the journal has established itself in the field of European studies. Moreover, BJES has become an international journal dedicated to the research of a wide range of issues related to the developments not only in the European Union, but also focusing on topics between the EU and other regions, such as EU Eastern partnership countries (Muravska, 2014) and Asia-Pacific countries (Chaban \& Holland, 2013). This strategic expansion is largely the result of the cooperation of BJES with the electronic publisher De Gruyter Open (former Versita) since 2013.

In the process of globalisation, where Europe needs a new understanding of financial and economic integration concerning all EU Member States, the mission of the Baltic Journal of European Studies will be to contribute to these processes by providing an open forum for academic discussions (Kirch \& Tuisk, 2013). In 2015, a new strategic step will be made by not merely continuing to expand the journal's geographical scope, but broadening our focus and competences by extending our Editorial Board with new members from the field of European and international law. In addition to these changes in the Editorial Board, we would also like to thank Dr. Aksel Kirch for his enormous contribution and personal efforts as Editor-in-Chief since 2002, the very beginning of the journal, which was then called Proceedings of the Institute of European Studies. Also, as Chairman of the Editorial Board in 2009-2014 Prof. Dr. András Inotai has contributed to the journal's internationalisation and evolution. In 2011, he became Honorary Doctor in the field of International Economics by the Tallinn University of Technology.

The new strategy of the journal is not to change its disciplinary focus but rather to broaden it. So far, the approach of the journal has been traditional, looking at the European studies from the perspective of European politics. However, an exhaustive analysis of European social issues cannot be successful without a detailed overview of economic developments. In principle, the same concerns the legal environment of the European Union and the whole continent, especially 
in these current troubled times. Owing to these reasons, the Tallinn Law School became an equal contributor to the journal alongside the Tallinn School of Economics and Business Administration.

Economy can flourish in a continuous way only if agreements between the interest groups, stakeholders and states are secure. However, this assumption is questionable in terms of commitments in the international, i.e. European legal space today. Further legal scholarly contributions are expected to discuss topical issues related to the rule of law in general and to contemporary problems in common understanding of legal certainty, e.g. amongst lawyers and decisionmakers, in particular. To illuminate this aspiration, we refer to Van Hamel, a Dutch lawyer and politician, who almost seventy years ago believed that "the object of the work of every lawyer is to find means of controlling this mysterious machinery which we call the human soul, of keeping it on a right track at the right speed" (Van Hamel, 1946). Today there is another serious challenge for researchers-we are living in the age of communication and technology and information has become a powerful weapon in influencing and even regulating both economy and legal policies. In Europe, technology and law should complement one another (Nyman-Metcalf, 2014), and legal scholars should make serious efforts to advance the still unshaped framework of e-regulation.

European studies have been always associated with integration issues. We hope that the journal will become an even more meaningful contribution to the scholarly debate and argumentation. In addition to analysing trends in political, legal and economic subject matters related to Europe, BJES is aimed at providing quality academic solutions and perspectives.

Peeter Mü̈rsepp and Tanel Kerikmäe, Editors-in-chief

\section{References}

Chaban, N. \& Holland, M. (2013), 'Seeing the EU from Outside its Borders: Changing Images of Europe,' Baltic Journal of European Studies, vol. 3, no. 3(15), pp. 3-12. http://dx.doi.org/10.2478/bjes-2013-0018

Kirch, A. \& Tuisk, T. (2013), 'On the Profile of the Baltic Journal of European Studies (BJES),' Baltic Journal of European Studies, vol. 3, no. 1(13), pp. 2-5. http:// dx.doi.org/10.2478/bjes-2013-0001 
Muravska, T. (2014), 'EU Eastern Partnership and New Challenges for Europe,' Baltic Journal of European Studies, vol. 4, no. 2(17), pp. 3-4. http://dx.doi.org/10.2478/ bjes-2014-0011

Nyman-Metcalf, K. (2014), 'e-Governance in Law and by Law,' in T. Kerikmäe (ed.) Regulating eTechnologies in the European Union: Normative Realities and Trends, Cham, Heidelberg, etc.: Springer Verlag, pp. 33-52.

Van Hamel, J. A. (1946), Report of the 41st Conference of the International Law Association, Cambridge: International Law Association, Cambridge Press. 